\title{
POR OUTRA ESCRITA FILOSÓFICA: METAFÍSICA, POESIA E EXCRITA - A PARTIR DE JEAN-LUC NANCY ${ }^{1}$
}

\author{
Carlos Cardozo Coelho ${ }^{2}$ \\ Universidade do Estado do Rio de Janeiro (UERJ) \\ https://orcid.org/0000-0001-7331-4009 \\ E-mail: cardozocoelho@gmail.com
}

\section{RESUMO:}

Neste artigo, apresentamos a necessidade de se repensar o estilo de escrita da Filosofia a partir de uma mudança de paradigma conceitual. O que importa à Filosofia e à "forma tratado de ontologia" é encontrar uma forma de dizer a Verdade, de dizer aquilo que é invariável. Ao encontrar esta forma, busca-se criar uma hierarquia de estilos, começando por aquele que diz a Verdade que, de fato, seria a única forma de escrever sobre o Ser e a existência, indo até os estilos que ocupam função política e retórica, até chegar à poesia, o discurso com menor comprometimento com a verdade e o bem comum. Se não defendemos mais a existência de uma verdade única e não pensamos mais a linguagem como instrumento para alcançar esta Verdad, que estaria Fora do Mundo, mas no lugar disso, pensamos a existência como singular-plural e toda "verdade" como um constructo de relações no interior de um mundo, que será sempre um mundo entre outros mundos, então a própria filosofia precisa repensar o seu estilo e a sua forma. Partindo desta demanda inelutável para um pensamento da diferença apresentaremos os argumentos de Jean-Luc Nancy (mas também os de Jacques Derrida) que sustentam esta necessidade de repensar a escrita.

PALAVRAS-CHAVE: Escrita; Ontologia; Poesia; Desconstrução

\section{FOR ANOTHER PHILOSOPHICAL WRITING: METAPHYSICS, POETRY AND EXCRIBING - FROM JEAN-LUC NANCY}

\section{ABSTRACT:}

In this article, we introduce the need of rethinking the writing style of Philosophy from a change in the conceptual paradigm. What matters to Philosophy and to the "form treatise of ontology" is to find a way of saying the Truth, to say which is invariable. When finding this form, it seeks to create a hierarchy of styles, beginning from whom says the Truth, which, in fact, would be the only way to write about the Being and the existence, to the styles that occupy a political and rhetorical function and to poetry, at last, the discourse with less commitment to the truth and the common good. If we no longer advocate the existence of a single truth and we no longer think of language as an instrument to achieve this Truth, that would be Out of the World, but instead of that, we think of existence as singular-plural and all "truth" as a construct of relations in the interior of a world, that will always be a world among other worlds, then philosophy itself must rethink its style and form. Starting from this ineluctable demand for a thought of difference, we will present the arguments of Jean-Luc Nancy (but also those of Jacques Derrida) that support this need of rethinking the writing.

KEYWORDS: Writing; Ontology; Poetry; Deconstruction.

\footnotetext{
${ }^{1}$ O presente trabalho foi realizado com apoio da Coordenação de Aperfeiçoamento de Pessoal de Nível Superior Brasil (CAPES) - Código de Financiamento 001

${ }^{2}$ Doutor em Filosofia pela Pontifícia Universidade Católica do Rio de Janeiro (PUC-RIO), Rio de Janeiro - RJ, Brasil, com estágio sanduíche na Université de Paris X - Nanterre la Défénse, Paris, França. Professor colaborador e pós-doutorando em Filosofia na Universidade do Estado do Rio de Janeiro (UERJ), Rio de Janeiro - RJ, Brasil, com bolsa da CAPES-PNPD.
}

COELHO, Carlos Cardozo. Por outra escrita filosófica: metafísica, poesia e excrita - a partir de Jean-Luc Nancy. Griot : Revista de Filosofia, Amargosa - BA, v.18, n.2, p.362-374, dezembro, 2018. 
Jean-Luc Nancy, no seu livro "Être Singulier Pluriel", possui o ambicioso projeto de repensar a filosofia primeira a partir do conceito heideggeriano de ser-com, segundo o que Nancy chama de a essência singular plural do ser. Contudo, antes de desenvolver seus conceitos, o filósofo crê ser fundamental também repensar - na esteira de Nietzsche e também de Derrida - a própria forma da escrita filosófica.

Como escrever um tratado sobre o ser se este ser - ou melhor, isto que é ser (existir) - não é mais Um, mas singular e plural ao mesmo tempo? Ainda faz sentido esta forma de escrita comprometida com um ideal de Verdade, de Origem e de Unidade? Em que medida os conceitos desenvolvidos por uma filosofia ou por um pensamento e a forma que escrevemos e apresentamos estes conceitos podem ser pensadas de maneira separada? A velha oposição tão cara à filosofia entre forma $\mathrm{e}$ conteúdo se apresenta como problemática aqui.

Como afirma Nancy no seu "tratado" - incompleto - de ontologia,

\begin{abstract}
Este texto não dissimula a ambição de refazer toda a "filosofia primeira" dando-lhe por fundação o "singular plural" do ser. Não é uma ambição do autor, mas uma necessidade da coisa mesma, e de nossa história. Eu espero, ao menos, fazer sentir esta necessidade. Mas ao mesmo tempo, além da força que me faltaria para executar o tratado da "essência singular plural do ser", a forma tratado de ontologia não é mais aquilo que convêm, logo que o singular plural do ser mesmo, e portanto aquele de sua ciência, estão em questão (NANCY, 2013, p.13).
\end{abstract}

Ora, o que propõe Nancy nesta passagem senão a necessidade de repensar a escrita e o estilo da filosofia? Mas que escrita é essa que é considerada como a verdadeira escrita filosófica a qual Nancy tenta se distanciar? De maneira simplória, poderíamos dizer que é a escrita que denega o próprio estilo da escrita, como veremos. É a sobrevalorização do conteúdo do dito sobre a forma como se diz. O que importa à filosofia e à "forma tratado de ontologia" é encontrar uma forma de dizer a Verdade, de dizer aquilo que é invariável, e, ao encontrar esta forma, criar uma hierarquia de estilos, começando por aquele que diz a Verdade, que, de fato, seria a única forma de escrever sobre o Ser e a existência, indo até os estilos que ocupam função política e retórica, até chegar à poesia, o discurso com menor comprometimento com a verdade e o bem comum.

Poderíamos dizer que filosofia parou (se é que tinha, de fato, começado antes), a partir da formulação da "Lógica" de Aristóteles, de pensar a questão da forma de escrita, mas não percebeu que a própria escrita fundada pela lógica já é uma entre diversas formas possíveis de dizer aquilo que é, de dizer o que é ser. A origem dessa denegação está no conceito de Verdade, de Origem e de Presença por trás da metafísica. Ao acreditar que há algo de invariável e inequívoco no mundo e que a nossa linguagem é equivoca, Aristóteles tenta criar condições para que seja possível dizer algo de verdadeiro sobre aquilo que é, sobre o ser.

Como afirma o filósofo grego, fundador de toda a teoria da linguagem ocidental pré-estruturalista, "Os sons emitidos pela voz são símbolos dos estados de alma e as palavras escritas, símbolos das palavras emitidas pela voz" (1, 16 a 3). E continua o filósofo,

Assim como a escrita não é a mesma para todos os homens, as palavras faladas também não o são, enquanto os estados de alma, de que estas

COELHO, Carlos Cardozo. Por outra escrita filosófica: metafísica, poesia e excrita - a partir de Jean-Luc Nancy. Griot : Revista de Filosofia, Amargosa - BA, v.18, n.2, p.362-374, dezembro, 2018. 
expressões são imediatamente os signos, são idênticos para todos, como são idênticos também as coisas de que estes estados constituem as imagens (1, 16 a $5 \mathrm{~s})$.

Para Aristóteles, existem dois níveis que são comuns para todos os homens: o plano das coisas e o plano dos estados de alma que antecederiam o plano da linguagem (da fala e da escrita), plano no qual existe a polissemia, ou seja, existe algo que é independente dos homens e para cada coisa os homens têm um estado de alma em si, mas cada palavra falada ou escrita pode significar mais de um estado de alma. A relação entre as coisas e os estados de alma é uma relação de analogia enquanto que a relação da linguagem é uma relação simbólica, isto é, a linguagem ordinária é fundamentalmente equívoca. Destarte, para Aristóteles a partir da fala e da escrita seria impossível dizer aquilo que existe de verdadeiro.

É por isso que o filósofo grego funda a sua lógica justamente para superar essa equivocidade, com esta ferramenta a filosofia passa a encontrar seu vocabulário mais próprio, a única forma possível de expressar algo de verdadeiro. Eis o nascimento, a grosso modo, do que é o estilo na filosofia, ou melhor, o nascimento daquilo que será por milênios após Aristóteles a história da denegação dos estilos pela filosofia (e também a denegação da poesia), relegando todo o discurso que não é estruturado segundo as regras da lógica ou como contrassenso, ou como retórica vazia, ou como poesia. Não é atoa que Aristóteles, além da Lógica escreveu também a Poética e a Retórica as definindo como disciplinas distintas da Lógica. Tanto o político, como o poeta, acabam se afastando da Verdade, ao adornarem a linguagem para atingir um efeito - seja estético, seja político.

Outro pensador da linguagem comprometido com o ideal de Verdade e de Presença é Frege. Este lógico define o referente como o objeto acerca do qual uma expressão denota, ou ainda como a "matéria" em cima da qual a linguagem significa (cf. DUCROT, O. TODOROV, T., 1988, verbete referência). Em contrapeso, o sentido é o movimento antagônico, a saber, a forma que designamos aquilo que visamos, ou, numa terminologia fenomenológica: "a linguagem é por excelência intencional, visa a outra coisa que ela mesma" (RICOEUR, 2000, p. 121). Para explicar esta, Frege usa o célebre exemplo do planeta Vênus. Segundo ele, o referente "Vênus" - planeta que orbita no sistema solar - possui dois sentidos: pode ser designado ao amanhecer como "estrela matutina" e ao anoitecer como "estrela vespertina".

Com este exemplo, conclui-se que um referente pode ser visado de diferentes formas, possuindo diversos sentidos para significá-lo. Esta distinção atesta que a linguagem sempre se enraíza num plano exterior a ela mesma, pois caso não o fizesse ela nada poderia dizer. Para Frege não há discurso possível sem um sentido designando uma referência, como sintetiza Ricoeur, apontando para a linguagem sobre a base desta dupla visada, sentido e referência: "Se o sentido [Sinn] pode ser dito inexistente, enquanto puro objeto de pensamento, é a referência - a Bedeutung que enraíza nossas palavras e nossas frases na realidade", "é na instância do discurso que a linguagem tem uma referência. Falar é dizer alguma coisa de alguma coisa" (RICOEUR, s/a; p.88).

COELHO, Carlos Cardozo. Por outra escrita filosófica: metafísica, poesia e excrita - a partir de Jean-Luc Nancy. Griot : Revista de Filosofia, Amargosa - BA, v.18, n.2, p.362-374, dezembro, 2018. 
Com efeito, a dupla articulação de Frege é a mola da predicação, na medida em que "dizer algo" designa a idealidade do sentido, e "dizer sobre alguma coisa" designa o movimento do sentido à referência. (ibidem).

Em contrapartida ao que foi dito sobre Aristóteles e Frege, o que defendemos neste texto é que não existe estilo de escrita que não seja desde o começo político e que o discurso de toda a metafísica da tradição - com suas oposições entre bem e mal, verdade e mentira, o claro e o obscuro, o homem e a mulher, o humano e o nãohumano etc. - é utilizada como força repressora de todas as formas de pensamento que não se adéquam ao padrão metafísico de pensar. Assim, pensar outras formas de estilo, implica necessariamente em pensar outra ontologia. Voltemos a denegação da filosofia,

\begin{abstract}
A recusa filosófica do estilo é talvez demasiadamente afamada, doravante, enquanto denegação, evitamento, apótrope e preterição. Sabe-se doravante bem que a filosofia cobiça o estilo, todos os estilos. Não se trata de negá-lo. Mas resta-nos talvez pensar o que, ao lado da cobiça, apesar dela, é também verdade. É o que se quer dizer aqui: que o pensamento, na verdade (o pensamento da verdade), nada tem a ver com o "estilo". (NANCY, 2011, p.83).
\end{abstract}

O que o pensamento da Verdade, o pensamento que está sempre endereçado a algo fora da linguagem, mas algo que é dado em si mesmo, algo de univoco que transcende a equivocidade da linguagem, tem a ver com o estilo? Resposta de Nancy: nada. Se existe algo como uma verdade univoca, todas as variações de sentido são ou erros, ou formas distintas de dizer a mesma coisa. É do mesmo que se trata: um mesmo sem outro, ou melhor, o outro é sempre o outro de um mesmo. Para esta tradição da Verdade e da Presença, a tradução e a metáfora são apenas mecanismos de dizer o mesmo de outra forma, o "acerca de que se fala" permanece. Não podemos dizer nada outramente, não há o outro enquanto outro.

E continua Nancy na página seguinte.

A escolha, à qual se expõe a filosofia, não é senão a escolha de ter um estilo
- e consequentemente, de não pensar mais o estilo, a essência do estilo, e de
não se pensar a si mesma -, ou de, de todo, não o ter, e, desta vez, de não
pensar de todo, se pensar requer estilo, porte, postura e atitude. Ela tem
assim a escolha entre dois suicídios. Mas a filosofia é por essência não
suicidária. (NANCY, 2011, p.84).

Ou a filosofia tem um estilo, isto é, ou jura dizer a Verdade, apenas a Verdade e tão somente a Verdade, ou a filosofia denega o estilo como uma questão secundária, trivial, em suma como uma não-questão. Ser ou não-ser, Verdade ou mentira, ou o Tudo ou o Nada, eis o suicídio intrínseco e genitor da filosofia, mas suicídio sempre denegado, recusado. Do sentido à sua referência, da escrita aos estados de alma e ao plano das coisas, não se pode dizer outramente, não se pode escapar ao logos apofântico, ao querer dizer enquanto querer dizer algo de algo, dizer algo do mesmo.

Aqui neste momento do texto, com Nancy como espectro que obsedia cada palavra proferida, mas também com Derrida, com Saussure e com Nietzsche, peço perdão à vocês que leem estas linhas, mas peço perdão também a Aristóteles e a 
Frege, peço perdão, "perdão por não querer dizer". Contudo não pedirei apenas o "perdão por não querer dizer", peço também, à vocês e à estes filósofos da Verdade, peço como uma prece repetida obsessivamente diante dos espectros que me são impostos, lhes suplico na incerteza e no segredo da resposta:"noli me tangere", "não me toquem", "não queiram me tocar".

Derrida inicia o último capítulo de Donner la mort, comentando esta frase: "perdão por não querer dizer...".

$O$ filósofo se pergunta o que é que este enunciado, isolado de qualquer contexto, pode significar: seria ele uma frase? Ou, quem sabe, uma prece? Talvez um pedido interrompido? "Um arqueólogo pode também se perguntar se esta frase está completa: 'Perdão por não querer dizer...' mas o que ao certo? E à quem? De quem a quem?" (DERRIDA, 1999, p. 163). Em suma, este enunciado (sem contexto, sem locutor, sem interlocutor e sem a certeza de ser uma frase concluída) exprime apenas um segredo, nada além de um segredo absoluto.

Entre todos aqueles que, em número infinito na história, guardaram um segredo absoluto, um segredo terrível, um segredo infinito, eu penso em Abraão, na origem de todas as religiões abraâmicas. Mas na origem também deste fundo sem o qual isto que chamamos de literatura não teria, sem dúvida, nunca podido surgir como tal, pelo menos não sob este nome. O segredo de alguma afinidade eletiva aliaria, assim, o segredo da aliança eletiva entre Deus e Abraão. (DERRIDA, 1999, p. 163).

E continua Derrida:

\begin{abstract}
Abraão poderia ter dito, mas Deus também: "perdão por não querer dizer...". Eu penso em Abraão que guardou o segredo, não falando nem com Sarah nem mesmo com Isaac, por causa da ordem que lhe foi dada, cara-a-cara, por Deus. Desta ordem, o sentido permanece secreto. Tudo o que sabemos é que é a demanda por uma prova. Mas qual prova? (DERRIDA, 1999, p. 163).
\end{abstract}

Abraão seria aquele que, mesmo podendo dizer, não queria fazê-lo; ele não queria trair as palavras de Deus. A interpretação que Derrida encaminha desta passagem é, então, de que a provação de Abraão era a de tentar guardar um segredo, de "não querer dizer".

Ele tinha a "liberdade" de poder trair a Deus, de explicar a seu filho que o levava ao seu sacrifício, ou de simplesmente não o levar. Contudo, Abraão, talvez o mais fiel dos fiéis, escolheu sacrificar o seu filho em silêncio. "Perdão por não querer dizer..." seria, então, as palavras que, a cada passo diante da longa caminhada ao Monte Mória, estariam engasgadas na "garganta fiel", como uma espécie de prece silenciosa, uma prece à seu filho, mas também à Deus.

Unilateralmente assinalada por Deus, a provação imposta sobre o Monte Mória consistiria em provar, justamente, se Abraão é capaz de guardar um segredo: de "não querer dizer...", em suma. Até à hipérbole: lá onde não querer dizer é tão radical que quase se confunde com um "não poder querer dizer". (DERRIDA, 1999, p. 164).

COELHO, Carlos Cardozo. Por outra escrita filosófica: metafísica, poesia e excrita - a partir de Jean-Luc Nancy. Griot : Revista de Filosofia, Amargosa - BA, v.18, n.2, p.362-374, dezembro, 2018. 
Desta forma, não apenas Abraão poderia pronunciar o enunciado, "perdão por não querer dizer...", mas, como diz Derrida, também Deus poderia pronunciá-lo, pois Ele incumbiu Abraão de uma missão, talvez a mais cruel das missões - a saber, sacrificar o seu próprio filho -, e manteve a finalidade - talvez a ausência dela - em segredo.

\begin{abstract}
Mas esperamos ainda para ver como esta prova do segredo passa pelo sacrifício deste que é o mais caro, o maior amor do mundo, o único do amor mesmo, o único contra o único, o único pelo único. Por que o segredo do qual nós vamos falar não consiste em esconder alguma coisa, em não revelar a verdade, mas em respeitar a absoluta singularidade, a separação infinita deste que me liga ou me expõe ao único, a um como a outro, ao Um como ao Outro. (DERRIDA, 1999, p. 165).
\end{abstract}

Diante deste segredo devemos pedir perdão por não poder querer "dizer algo de alguma coisa"; devemos pedir perdão a Aristóteles e a todos os seus seguidores, pois, diante da ausência da revelação de um Pai, da melancolia e da espera pela língua perfeita, eles acabaram crendo transpor a barreira que separa as línguas. Em suma, mesmo se o homem quisesse dizer, e ele o quer, Deus diria antes dele concluir sua frase, assim como disse aos Sem, Babel: confusão.

Enquanto os Sem, no mito de Babel, foram contra Deus e afirmaram uma Verdade linguística, Abraão seria aquele que se resignaria diante da palavra de Deus, diante da(s) palavra(s) do Mundo, ou seja, ele seria aquele que compreenderia plenamente o que é um segredo, o que é a confusão imposta aos homens por Deus: viver sobre a lei da escritura.

Porque o Deus de Abraão, de Isaac, e de Jacob, diferentemente do Deus dos filósofos e da ontoteologia, é um Deus que se retracta. Mas há que não dar à pressa nomes mais tardios ao re-traimento desta retracção anterior ao arrependimento, à pena, ao remorso. (DERRIDA, 1999,p. 154 ).

O homem que pede "perdão por não querer dizer", o homem que escutou ao Deus babélico seria aquele que seguiria os passos de Abraão; aquele que, a cada passo em direção ao Monte Mória, à todos os Montes Mória que a ele se apresentam, pronunciaria, como uma prece obsessivamente, "Babel, Babel, Babel...". Aquele que saberia que "a coisa mesma sempre escapa", que não há Estados de Alma e plano das coisas que seja imóvel e que se apresente enquanto tal: o mundo só se apresenta na medida em que se retrai, se retrata.

Essa frase faz visivelmente referência. É uma referência. Um leitor francês compreende as suas palavras e a ordem sintática. $O$ movimento da referência é nela irrecusável ou irredutível, mas nada permite parar, em vista de uma determinação plena e segura, a origem e o fim desta prece. Nada nos é dito do signatário, do destinatário e do referente. (DERRIDA, 1999, p. 160).

Esta frase é então lançada no (e ao) segredo absoluto, contra Frege e Aristóteles, ela tem e faz referência, ela tem e faz sentido, mas sentido retraído, 
retirado, em suma, como rastro de uma verdade perdida nos confins do pluriversos das verdades.

O inquiridor vê-se já então numa situação que não seria mais a de um
interprete, de um arqueólogo, de um hermeneuta, de um simples leitor, em
suma, com todos os estatutos que se pode reconhecer a este: exegeta de
textos sagrados, detetive, arquivista, mecânico de maquina de tratamento
de texto, etc. [...] Tudo está entregue ao porvir de um «talvez». [...] Perdão
por guardar o segredo, e o segredo de um segredo, o segredo de um
enigmático «não querer dizer», de um não-querer-dizer-este-ou-aquele
segredo, de um não-querer-dizer-o-que-eu-quero-dizer - ou de não querer
de todo dizer, ponto. Duplo segredo, ao mesmo tempo público e privado,
manifesto no retraimento, tão fenomenal como noturno. (DERRIDA,
1999, p. 160-161).

Não há mais aqui lugar para interpretações, para arqueologias, para hermenêuticas, o sentido aqui não é mais o sentido de um querer dizer, mas, ao contrário, a impossibilidade do sentido enquanto querer dizer, ou melhor a afirmação do nao-sentido como mais fundamental que o sentido: a afirmação de que o sentido advêm de um nada, mas de um nada que já é alguma coisa, que é a abertura para os outros, ou outros enquanto espectros e aparições singulares, enquanto repetições cada vez únicas.

Diante deste segredo instaurado por Deus só podemos afirmar uma coisa, o próprio segredo, a própria impossibilidade da revelação de qualquer sentido pleno, pois a única coisa que se revela é aquela que se retraí no mesmo momento da revelação. Em síntese, só podemos, como já dissemos, afirmar a confusão, a impossibilidade da linguagem enquanto forma de expor a Verdade. É só a partir desta multiplicidade que traz a confusão que há algo para ser sentido.

Abraão e Isaac nos mostraram o peso do segredo e que em todo dizer há antes um não - poder - querer dizer que o determina. Agora analisemos um outro texto bíblico, a narrativa da ressurreição de Cristo, a cena na qual Jesus profere a Maria Madalena, noli me tangere, "não me toque", não queira me tocar.

\footnotetext{
Não há nada nem ninguém a mostrar, nada nem ninguém a desvelar ou revelar. O pensamento da revelação como colocada a luz de uma realidade escondida ou bem como o deciframento de um mistério só é uma modalidade religiosa ou crente (no sentido de uma representação ou de um saber subjetivo) do cristianismo ou do monoteísmo em geral. Mas na sua estrutura profunda, não religiosa [...] e não crente, a "revelação" constitui a identidade do revelável e do revelado, do "divino" e do "humano" ou bem do "mundano". (NANCY, 2003, p.9-10).
}

O segredo de Abraão não possuía um querer dizer velado, era um segredo absoluto, a revelação do segredo já lhe dava a sua própria identidade, ele não possui sentidos escondidos ou a serem revelados, o próprio segredo já é o que se tem a ser revelado. $\mathrm{O}$ mistério de uma realidade escondida estaria ainda na lógica do querer dizer, na lógica que quer que o sentido seja parado por uma significação específica e inerte, já verificada. Em contrapartida, assumir o segredo e o mistério como aquilo 
que se revela sem fundo é deixar o sentido aberto, entender que o sentido se movimenta, ele é passagem, envio, reenvio, partida.

Assim a frase "não me toque", proferida por Jesus após voltar ao mundo dos vivos,

enuncia alguma coisa do tocar em geral ou ela toca o ponto sensível do tocar: à este ponto que ele constitui por excelência (ele é em suma "o" ponto do sensível) e à este que nele forma o ponto sensível. Ora este ponto é precisamente o ponto onde o tocar não toca, não deve tocar para exercer seu toque (sua arte, seu tato, sua graça): o ponto ou o espaço sem dimensão que separa isto que o tocar junta, a linha que rompe o tocar do tocado e então o toque dele-mesmo. (NANCY, 2003, p.25).

O tocar não toca, ou melhor, apenas toca ao tocar o intocável, pois não há o tocável enquanto tal, o que existe são espectros e aparições, aparições enquanto reaparições. E continua Nancy,

Em nenhum outro momento Jesus proibiu ou recusou que o tocassem [...]. Isto que não é para ser tocado, é o corpo ressuscitado. Nós podemos também compreender que ele não deve ser tocado porque ele não o pode ser: ele não é para tocar. Isto não significa entretanto que se trate de um corpo aéreo ou imaterial, espectral ou fantasmagórico [...]. Seu ser e sua verdade de ressuscitado estão neste afastamento, nesta retirada que só dá a medida do toque do qual deve se tratar: não tocando este corpo, tocar à sua eternidade. Não vindo ao contato de sua presença manifesta, acessar à sua presença real, que consiste na sua partida. (NANCY, 2003, p.28).

A presença real de toda aparição - o que a ressurreição de Cristo parece atestar - é que não há nada de mais real que a partida, o movimento constante e inelutável de retirada. Como diz Nancy, no original grego da narrativa de João, Jesus diz: "mè mou haptou", que pode ser traduzido igualmente por "não me toque", mas também não me retenha, não me pare, pois o verbo haptein pode significar tanto tocar, quanto reter e parar. Da mesma forma, como dissemos, noli me tangere significa não me toque, mas também, não queira me tocar, ou seja, Maria Madalena não teria nem a opção de querer tocar, ou, para retomar o segredo de Abraão, Maria Madalena não podia se quer querer tocar. Não me toque, não queira me tocar, não me pare, não me retenha, não queira me parar, não queira me reter. Jesus então retorna da morte para a vida apenas para anunciar sua partida e para anunciar que ninguém pode tocá-lo, ninguém pode retê-lo ou pará-lo.

Jesus surge para afirmar um para além da vida e da morte, para afirmar a singularidade de cada aparição enquanto partida e cada partida enquanto retorno, retorno para que uma nova retirada aconteça.

Cristo não pode ser segurado, pois ele parte: ele o diz logo, ele ainda não se juntou ao Pai, e ele parte para ele. $\mathrm{O}$ tocar, o reter, seria aderir à presença imediata, e da mesma forma seria crer no tocar (crer na presença do presente), seria esquecer a partida segundo à qual o toque e a presença vem à nós. A "ressurreição" acha assim seu sentido não religioso. Isto que é para a religião recomeço de uma presença, portanto a segurança fantasmática de uma imortalidade, se revela aqui não ser outra coisa que a

COELHO, Carlos Cardozo. Por outra escrita filosófica: metafísica, poesia e excrita - a partir de Jean-Luc Nancy. Griot : Revista de Filosofia, Amargosa - BA, v.18, n.2, p.362-374, dezembro, 2018. 
partida na qual a presença se eleva em verdade, portanto seu sentido segundo esta partida. Como ela vem, ela parte: isto é, ela não é no sentido no qual alguma coisa é colocada na presença, imóvel, idêntica à si, disponível para um uso ou para um conceito. (NANCY, 2003, p.29).

E continua Nancy,

"não me toque" pois sua presença é uma desaparição indefinidamente renovada ou prolongada. Não me toque, não me retenha, não pense nem em me agarrar nem em me atingir, pois eu parto para o Pai, isto é ainda e sempre para a potência mesma da morte e eu me afasto nela, eu me fundo no seu brilho noturno nesta manha de primavera. Eu já parto, eu só sou/sigo nesta partida, eu sou o que parte da partida, meu ser nela consiste e minha fala é esta aqui: "eu, a verdade, eu parto". (NANCY, 2003, p.31).

Digamos mais uma vez então a Aristóteles e a Frege: não me toquem, não me retenham, não me parem, deixem que eu revele minha verdade, a minha partida. Assim a ressurreição na concepção que trabalhamos aqui é uma espécie de para além da morte e da vida:

Nem morto, nem vivo, não há simplesmente um presente. Mas sempre uma presentação de um ao outro, para o outro ou no outro: a presentação de uma partida (NANCY, 2003, p.36).

Em suma, noli me tangere quer dizer que o que se apresenta a nós não é uma coisa imóvel e indiferente à qual a linguagem visa, mas que o que se apresenta e pode ser tocado é a própria partida, ou seja, o intocável. Da mesma forma, o que pode ser dito é esta partida, não a retirada daquilo que é dito, mas o próprio dizer da retirada.

Voltemos a questão que conduz este texto: o que quer dizer escrever se escrever não está mais na lógica da ontoteologia, da metafísica da presença?

Se não existe mais uma verdade a ser revelada, ou melhor, se a verdade a ser revelada é a própria revelação de que 1) primeiramente há mais de um, 2) que antes de qualquer tipo de querer dizer há um segredo absoluto que o antecede, e 3) a verdade consiste na própria partida, na própria retração; então toda a concepção de linguagem defendida pela metafísica da presença não faz mais sentido, ou melhor, faz um sentido muito restrito, um sentido que denega o próprio sentido. É preciso então escrever outramente, em vez de significar e querer dizer algo de algo, devemos nos endereçar à escrita, a partir dela.

Eu não posso falar, isto é, eu não posso pensar, sem que este "sentido no outro" já ressoe "em mim".. "Passar do um ao outro" não é uma operação a mais para o pensamento. (NANCY, 2001, p.41).

E continua Nancy,

Desde Nietzsche, ao menos, e para todos os tipos de outras razões que se juntam sem dúvida naquela que eu evoco, a filosofia está mal com sua "forma", isto é com seu "estilo", enfim com seu "endereço". Como o pensamento se endereça - ao pensamento (isto que quer dizer também, à todo mundo, sem que se trate para tanto da "compreensão", do 


\begin{abstract}
"entendimento" que diríamos "comum")? Como o pensamento é no endereço? (O tratado de filosofia, e com ele a "filosofia" como tal, seria a neutralização do endereço, o discurso sem sujeito do Ser-Sujeito ele mesmo.) (NANCY, 2013, p.13).
\end{abstract}

Para Nancy o pensamento está muito mais no endereçar, neste movimento de se lançar à abertura que é cada alteridade - ou seja, pensar é a abertura a cada homem, a cada animal, mas também a cada planta, a cada bactéria, a cada vírus, a cada pedra, a cada estrela, a cada brisa que se endereça ao mundo e a nós, a este(s) mundo(s) que somos nós, em suma, é se endereçar a cada singularidade plural. E ser, para Nancy, é este co-enderençamento de cada ente sendo com cada ente, é a constatação que cada eu só é na medida em que faz mundo e é mundo junto com cada ente do mundo. A filosofia que quer dizer a verdade, é então a filosofia que denega o endereço e denega a poesia enquanto modo de acesso a esse endereço, pois acredita num ponto de vista neutro e impassível. Entretanto, não há existência que não seja, desde o princípio coexistência, ou seja, afetada pelos outros entes.

Dito de outra forma, o que é então o "diálogo da alma com ela mesma" do qual fala Platão[...]? Se o pensamento é endereçado, é porque o sentido é no endereço, não no discurso (mas no endereço do discurso). Isto mantêm a condição ontológica primordial do ser-com ou do ser-junto, do qual eu gostaria de falar. (NANCY, 2013, p.13-14).

Este ser-com é ser com a multiplicidade, com o segredo e com o intocável que é cada ente. Singular e plural ao mesmo tempo, secreto, intocável como nos mostram Abraão e Jesus, mas ao mesmo tempo plural. O singular plural é aquele que se endereça sem querer alcançar, sem a intenção do querer dizer, ele simplesmente se lança à multiplicidade de cada segredo e ao segredo de cada multiplicidade. Assim, para escrever essa outra ontologia

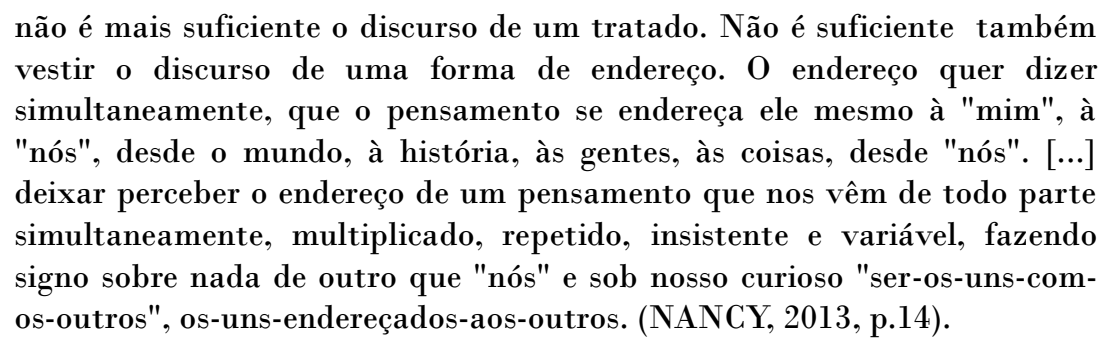

Não falamos até agora da poesia propriamente. Contudo, ela está nos obsediando a cada instante deste texto. Lá onde a metafísica tradicional relegava a poesia ao lugar do adorno, à cosmética, ao mero deleite linguístico, e a instaurava como radicalmente oposta a filosofia, nós defendemos, como já dissemos, que uma outra ontologia demanda necessariamente outra escrita, outro estilo e portanto, outra relação com a poesia. Como diz Jean-Luc, "Filosofia versus poesia não constitui uma oposição. Cada uma faz a dificuldade da outra. Juntas elas são a dificuldade mesma: de fazer sentido" (NANCY, 2004, p.11). 
Lá onde, por exemplo, um filósofo como Paul Ricoeur pensava a metáfora (Cf.1975) e o poder poético da linguagem como a capacidade de redescrever a realidade, ou seja, existiria Um real, o qual nós temos acesso a partir da nossa consciência, e existiriam várias formas diferente de nos relacionarmos com este real. A metáfora viva, em oposição a catacrese - a metáfora morta -, seria aquela que criaria novos nomes para se relacionar com a realidade, deslocando e criando novas culturas, novas línguas. Contudo, a natureza e o real independente do homem permaneceriam os mesmos.

Contudo a metáfora é, para Nancy, na esteira de Derrida, aquilo que se retira, ela é aquilo que impossibilita que o sentido seja parado, estagnado e aquilo que rompe com a lógica da Origem única, com a lógica da unidade e do fundamento. A metáfora é a retração, ela anuncia a impossibilidade do querer dizer algo de algo, a impossibilidade do toque ao fundamento.

Para Nancy, a poesia é justamente o modo de acesso ao sentido, só que o sentido para Nancy é uma coisa completamente outra.

\begin{abstract}
Se compreendemos, se acessamos de uma maneira ou de outra, uma orla de sentido, é de modo poético. Isso quer dizer que qualquer espécie de poesia constitua um medium ou um meio de acesso. Isso quer dizer - e é quase o contrário - que só esse acesso define a poesia, e que ela só acontece quando esse acesso acontece. (NANCY, 2004, p.14).
\end{abstract}

Assim, podemos dizer, que para Jean-Luc a poesia não é capaz de redescrever a realidade, pois não há a realidade fora do jogo de remessa de sentidos, o que existe é a poesia enquanto acesso ao sentido, enquanto capacidade de excrever (com x) o sentido. O prefixo latim "ex" quer dizer fora, aquilo que se dá na extremidade, no limite, na superfície de um toque. Com este prefixo acrescido à palavra escrever, Nancy quer dizer que excrever é se relacionar - e se endereçar - as alteridades, é inscrever aquilo que é cada vez singular com o qual nos relacionamos. A poesia é o apontar para o cada vez singular que cada um é. É apontar para a pluralidade de origens de mundo, de mundo. Mas para Nancy, o fora é dentro, não existe o Fora absoluto,

O sentido é o reenvio (a referência, a relação, o endereçamento, a recepção - a sensibilidade, o sentimento). Um mundo é a totalidade de reenvios, mas ele próprio não reenvia a nada de outro. Os mundos no interior do mundo - os mundos, por exemplo, do círculo polar ou da música indiana clássica, os mundos de Goya ou de Wittgenstein, das redes ou dos transistores - formam "o" mundo reenviando uns aos outros: mas "o" mundo não reenvia a nada.

Não há outro mundo, não há além-mundo nem "além mundos" (Nietzsche). O que quer dizer que não há reenvio último para a rede de reenvios do mundo, e que não há portanto Sentido (último) do sentido ou dos sentidos.

E continua Nancy,

Não há sentido do sentido: não é, feitas as contas, uma proposição negativa. É a própria afirmação do sentido - sensibilidade, sentimento, 
significação: a afirmação de acordo com a qual existentes do mundo, reenviando uns aos outros, abrem para o inesgotável jogo dos reenvios - e para nenhuma espécie de apresamento a que se chamaria "sentido da vida", "sentido da história", ou ainda "salvação", "felicidade", "vida eterna", como tão pouco para a imortalidade que seria a das obras, que não são elas mesmas senão formas e maneiras de reenvio. Em contrapartida, a verdadeira imortalidade - ou eternidade - que é a nossa, é precisamente dada pelo mundo enquanto lugar de reenvio mutuo infinito. (NANCY, 2014, p.26-27).

Não há sentido do sentido quer dizer simplesmente isto: o sentido está aqui, ele é aqui, entre nós, de um a outro. E não há um real enquanto tal para descrever e redescrever, o que há são mundos sendo construídos no interior de uma pluralidade de relações e de (co)presentações. Mas cada presentação se dá no modo do segredo do não poder querer dizer.

O que Nancy faz aqui e o que no seu pensamento nos interessa é a torção do conceito de sentido, o sentido não designa e nos envia a nenhuma transcendência Fora do mundo, mas nos mostra que o sentido é sempre reenvio, isto é, ele não é um envio originário, nem envio ao Originário, mas ele é este jogo de remessas sem começo e sem fim dos existentes, Derrida chamaria isto de escritura - o jogo dos rastros.

Eu me endereçando a vocês, vocês partilhando um espaço no mundo, aqui e agora, comigo, se endereçando a mim neste mundo que partilhamos, pois só há mundo no interior da partilha que nós somos. Dizer que não há um Fora absoluto não implica em dizer que não existam alteridades e fora(s), pelo contrário, é dizer que toda transcendência se efetua no interior de um mundo, no interior de um plano no qual os existentes se relacionam e fazem mundo.

Nancy chama este movimento, o Fora acontecendo Dentro, de transimanência: o infinito só se efetua no interior do finito, e a poesia é a porta de entrada para a infinitude do sentido. Cada existente que compõe este mundo é finito e absolutamente singular, mas este finito não é o finito da privação, pois ele carrega em si o infinito, que é a sua abertura para todos os outros entes do mundo. O sentido nada mais é do que essa abertura para todos os outros entes, é estar no jogo de remessa que é a existência, é se abrir ao infinito que é o fora, mas este infinito só se manifesta e se efetua, vale insistir, no interior de um mundo e é nele que experienciamos qualquer coisa ou qualquer tipo de relação.

Fazer mundo: "ofício" de poeta. A poesia não se escreve, ela se co-excreve. 


\section{Referências}

ARISTOTELES. Da interpretação, São Paulo: UNESP, 2013

DERRIDA, J. Donner la mort, Paris: Galilée, 1999

DUCROT, O. TODOROV, T., Dicionário enciclopédico das ciências da linguagem, São Paulo: Perspectiva, 1988

NANCY, J-L. Adoração: Desconstrução do Cristianismo II. Trad. port. de Fernanda Bernardo. Coimbra: Pallimage, 2014

. Etre, singulier, pluriel, Paris: Galilée, 2013

. Le sens du monde, Paris: Galilée, 2001

.Le pois d'un pensée. La Phocide, 1970 (Trad. port. de Fernanda

Bernardo. Coimbra: Pallimage, 2011)

. Noli me tangere. Paris: Bayard,2003

. Résistance de la poésie, Paris: William Blake \& co. 2004

RICOEUR, P. La métaphore vive, Paris: Le Seuil, 1975 (A Metáfora Viva, São Paulo:

Edições Loyola, 2000)

. O Conflito das Interpretações: Ensaios de Hermenêutica. trad. port. Artur

Morão. Porto: Rés-Editora, s/a

Autor(a) para correspondência: Carlos Cardozo Coelho, Universidade do Estado do Rio de Janeiro, R. São Francisco Xavier, 524, Maracanã, CEP 20550-900, Rio de Janeiro - RJ, Brasil. cardozocoelho@gmail.com 